\title{
Description of Occupational Safety and Health Promotion Program in PT. X 2017
}

\author{
Nanda Paramita Putri, Siti Rahmah Hidayatullah Lubis \\ Public Health Study Program, Faculty of Medicine and Health Sciences \\ Syarif Hidayatullah State Islamic University Jakarta, Indonesia \\ nandaparamitaputri@gmail.com
}

\begin{abstract}
Occupational Safety and Health Promotion is an attempt that created by PT. $X$ to apply Occupational Safety and Health in the company. Implementation is mandatory to provide information related to occupational safety and health and work facilities to be conducive to safety and health in work. Occupational Safety and Health Promotion can be done with various form of programs in accordance with the existing problems. This research was conducted by Occupational Safety and Health Unit and has done for 26 working days starting from February 1st until March 16th, 2017. The information about Occupational Safety and Health Promotion in company is obtained through interview, observation, and document review. In general, the implementation of Occupational Safety and Health Promotion at PT. $X$ in accordance with existing theories and policies. However, there are still some things that need to be considered in the implementation of each promotion program either based on existing theory and policies used as a reference in the implementation of the program. Suggestions given for improvement of Occupational Safety and Health Promotion program is to standardize the Occupational Safety and Health training module, conduct measurable and documented extension evaluation, make a video about Occupational Safety and Health in the company, make safety procedures to complement the implementation guidance of existing activities, and conduct the procedure of that promotion used as a reference in the implementation of each program that will run.
\end{abstract}

Keywords- Occupational Safety and Health Promotion Program; Training; Counseling; Communication and Consultation

\section{INTRODUCTION}

Development of the technologies used in an industry make the large potential of the danger incurred so it can be cause work accidents, fires, and occupational disease. According to the International Labor Organization (ILO), every year there are more than 250 million accidents in the workplace and over 160 million workers become ill cause hazards in workplace. Moreover, 1.2 million workers die from accidents and illness at work. The number of work accidents in Indonesia is still high [1]. According to data of Employee Social Security System, until the end of 2015 there have been work accidents as many as 105,182 cases [2]. As for data on the proportion of accidents in Indonesia it is known that in the construction and manufacturing sectors accounted for $32 \%$, different from the transportation sector (9\%), forestry (4\%) and mining (2\%) [3].

Even the small accidents and work-related diseases can provide both material and non-material harm, therefore an effort is needed to prevent this from happening. Prevention of occupational injuries and diseases is fundamental to the company, because it involves the human soul or its workforce and the work environment. In law regulation of Indonesia No. 11970 about occupational safety in section 3 (a) it is known that the safety requirements of occupational safety are to prevent and reduce accidents. In addition, a company is obliged to protect workers from the various dangers posed by the work process. The law regulation of Manpower No. 132003 about Manpower in $5^{\text {th }}$ paragraph of Occupational Safety and Health (K3), section 86 (a) provides that every worker has the right to obtain protection for occupational safety and health.

PT. X is one of the factories that produce paper. To process raw materials into finished materials that are diverse, these tech machines work continuously for 24 hours which of course has a risk of accidents, occupational diseases, and the occurrence of fires in the company. In order to avoid the consequences of that condition, an effort to control the potential and risk of the existing hazards is required. With these risks, the application of Occupational Safety and Health in the company must also be done in order to prevent the occurrence of occupational accidents and diseases, so that workers are healthy, safe, and can work optimally. One effort that can be done by a company to apply Occupational Safety and Health in the company, that is with the promotion of Occupational Safety and Health.

\section{METHOD}

The type of this research is descriptive research, where researchers try to describe the implementation of health promotion program in PT X. This research was conducted at PT. X from February to March 2017. The type of data used in this study is primary data and secondary data.

The information about Occupational Safety and Health Promotion in company is obtained through interview, observation, and document review. Interviews are conducted to stakeholders related to Occupational Safety and Health promotion, i.e, Occupational Safety and Health manager and person in charge of Occupational Safety And Health promotion program. Meanwhile, observations were made around the company to see the implementation of the Occupational Safety and Health promotion program there. Reviewing documents conducted by looking at data related to promotion of Occupational Safety and Health to relevant stakeholders. All 
data has been collected with methods above then descripted and compared to regulations and related theories.

\section{RESULT}

\section{A. The Regulation of Occupational Safety And Health Promotion Program in PT. X}

In general, the implementation of Occupational Safety and Health promotion program conducted at PT. X refers to law regulation of Indonesia no. 11970 about concerning Work Safety in section 9, paragraph 3. The other reference is the law regulation of Manpower No. 132003 in section 86 (2). However, there is one national regulation that has not become a reference in the implementation of Occupational Safety and Health promotion in PT. X namely Minister of Manpower Regulation No. 10 2016, section 14 (1). And PT. X have company policy, which one of the policy points among them related to the priority of Occupational Safety and Health, that is preventing work accident and work-related diseases.

In realizing one that policy, PT. X is doing Occupational Safety and Health promotional efforts are realized through training, counseling, communication and consultation, and Occupational Health and Safety awards. Some of Occupational Health and Safety promotion programs at PT. X have their own references in accordance with the program and already have Standard Operating Procedures (SOP) that become reference in every implementation. This SOP is a way to achieve the objectives of a program.

\section{Occupational Safety and Health Training}

The reference in the implementation of training in PT.X based on the procedure one of them is OHSAS 18001: 2007 in clause 4.4.2. Competence, training, and caring. In addition, the Occupational Safety and Health training program that has been conducted in PT. X refers to the law regulation of Manpower No. 132003 in section 11. The other reference is the law regulation of Indonesia No. 11970 about Occupational Safety in section 9 .

\section{Occupational Safety and Health Counseling}

As well as Occupational Safety and Health Promotion Training, the implementation of counseling programs conducted at PT. X is referring to law regulation of Indonesia No. 11970 about Occupational Safety in section 9.

\section{Occupational Safety and Health Communication and Consultation}

In conducting this program, the Occupational Safety and Health Unit refers to the DC/OP /01 procedure of internal communication and consultation. In carrying out the program, the Occupational Health And Safety Unit acknowledges the implementation of this program aims to ensure that all communication and consultation processes of sections and departments related to Occupational Safety And Health work well and ensure that Occupational Safety And Health communication and consultation activities and other important information are communicated and consulted to all employees on the DC/OP/01 procedure on internal communication and consultation.

\section{Occupational Safety and Health Award}

Other programs that are awarded K3 given by the company to the Department/Section/Employee who excel in the field of K3. The implementation of this program refers to the Regulation of the Minister of Manpower and Transmigration of the Republic of Indonesia Per.01/Men/I/2007 on Guidelines for Occupational Safety and Health Awards.

\section{B. Implementation Process of Occupational Safety And Health Promotion Program in PT. $X$}

The implementation stage of Occupational Safety and Health promotion program promotion in general is in accordance with the theory, that is the stage of planning, implementation, and evaluation [4]. The following is an explanation of the Occupational Safety and Health promotion program conducted at PT. X.

\section{Occupational Safety and Health Promotion Training}

The implementation of $\mathrm{K} 3$ training activities in PT. $\mathrm{X}$ is done through several stages, namely before training stage, training implementation, and training evaluation, and report making.

Stages before the training consists of several activities, namely training needs analysis, making Occupational Safety and Health training matrix, module making, and socialization of training implementation. And then, stage of training implementation in PT.X is generally consisted of several stages in the same training. After it, the stage is evaluation of Occupational Safety and Health training at PT. X is done in several ways.

The evaluation is done by assessing the satisfaction of the training that has been done (Training Service Satisfaction). In addition, the evaluation of Occupational Safety and Health training is based on the objectives of the training itself. Training that aims to improve participants' knowledge related to the Occupational Health and Safety training topics covered will be evaluated into training skill evaluations. As for training that aims to improve the behavior it will be done through the observation of the participants.

Training evaluation conducted at PT. X has reached the third stage based on a four-level model of Kirkpatrick training. Starting from the first level (reaction), second level (related to learning), and third level (evaluating behavior). However, the implementation of the evaluation has not reached the fourth stage, where at that stage the measurement is related to the extent to which the training program has helped the achievement of organizational goals that have been predetermined.

\section{Occupational Safety and Health Counseling}

Counseling is one of the activities undertaken at PT. X by unit Occupational Safety and Health to promote Occupational Safety and Health to all workers. This counseling is conducted every month, where the Occupational Health and Safety unit 
comes to the work area in each section to convey messages on Occupational Safety and Health aspects. This counseling aims to invite all workers to always be cultured Occupational Safety and Health in doing their daily work. The counseling is based on a predetermined schedule by the Occupational Safety and Health unit or performed on a case basis. If a case is found in a section then for the next shift workers will be directly given counseling.

Counseling conducted at PT.X done through several stages, i.e, review needs, retting problems and prioritizing problems, setting goals, schedule determination, topic determination, and preparation of material.

\section{Occupational Safety and Health Communication and Consultation}

According to Big Indonesian Dictionary, communication is the sending and receiving of messages or news between two or more people so that the intended message can be understood. Communication is a form of human interaction that affects each other, intentionally or unintentionally and is not limited to verbal communication, but also in terms of facial expression, painting, art, and technology [5].

Forms of communication that is Occupational Safety and Health orientation, and communication to workers. Communication to workers is done by conveying messages or information to workers regarding the use of PPE in the workplace, such as the use of earplugs, earmuffs, masks, etc. along with the benefits of use for worker health. This communication is also conducted in relation to other aspects of occupational safety at work, and some media used in delivering messages or information to be conveyed.

Consultation in Indonesian Dictionary is an exchange of thoughts to get the best conclusions (advice, suggestions, etc.). Consultation aims to provide help for the target, focusing on human relationships, helping targets for perception, understanding, and acting, in activities within the environment. Consultation can also be done to change the behavior of individuals or groups [6].

The following is a consultation conducted at PT.X i.e,:

a) A consultation is made if a case or problem is found in the worker's medical check-up result

b) Workers who will rotate the work will be consulted by the Occupational Safety and Health unit in relation to their work as well as the Occupational Safety and Health unit will at the same time provide an orientation of the health hazards to be found in his new job.

c) The consultation is conducted with regard to the determination of fire equipment

d) Consultations made from certain sections to Occupational Safety and Health units relate to aspects of occupational safety and health in the event of modifications of the equipment, materials and technologies used in the paper production process.

e) Occupational Safety and Health daily consultation conducted to provide freedom for workers in determining the areas of consultation appropriate to their problems or desires.

\section{Occupational Safety and Health Award}

As one of the efforts to promote K3 in the workplace, PT. $\mathrm{X}$ has implemented the Occupational Safety and Health Awards program. The program is a mark of safety and health awards provided by Top Management PT. X to Head of Division, Head of Department, Section Head, Member of P2K3 and Occupational Safety and Health Diligent who has succeeded in implementing Occupational Safety and Health program in PT. $\mathrm{X}$.

The implementation process of this award begins from the assessment stage undertaken by relevant stakeholders according to the type of award that will be awarded up to the pre-determined awarding stage. After the assessment in accordance with the award category, then performed the Occupational Safety and Health awards.

\section{DISCUSSION}

\section{A. The Regulation of Occupational Safety And Health Promotion Program in PT. $X$}

The following will discuss the suitability of the implementation of occupational safety and health promotion program at PT. X with related regulation.

In the implementation of Occupational Safety and Health training, the implementation has been in accordance with existing training procedures. The procedure referred to is a general training procedure owned by the People \& Organization Development section or in other words the Occupational Safety and Health unit does not have its own training procedure.

Occupational Safety And Health Counseling programs conducted at PT. X are in conformity with the relevant policy because it refers to law regulation of Indonesia No. 11970 about Occupational Safety in article 9, which reads "The Board is obliged to show and explain to each new worker about the conditions and dangers and which may arise in the workplace..."

The other programs, such as occupational health and safety communication and consultation and awards has also followed the national regulation in Indonesia.

\section{B. Implementation Process of Occupational Safety And Health Promotion Program in PT. $X$}

Occupational Safety and Health promotion is a promotional effort that is held in the workplace, in addition to empowering people in the workplace to recognize the problem and their health level, and be able to cope, maintain, enhance and protect their own health and safety as well as maintain and improve healthy workplaces [7]. Occupational Safety and Health promotion in the workplace can be done through various forms that are realized into certain programs in a workplace in accordance with the existing problems. The aim is to provide information about occupational safety and health and to modify employee behavior to be conducive to safety and health in work [8]. 
In developing the Occupational Safety and Health promotion program in the workplace there are several stages that need to be done so that chosen the appropriate health promotion program in overcoming the problems that exist in a workplace, and known how the program is implemented. Just as it is done by PT X, the development of Occupational Safety and Health promotion program that will be conducted in the company through several stages.

In general, the implementation stage is applied in accordance with the theory, i.e, the stage of planning, implementation, and evaluation [4]. It's just that the whole stage of implementation is documented in writing. Documentation related to the implementation of the Occupational Safety and Health program development in the company is important so that there is clarity on the vision, mission, objectives, scope, policies and procedures for the implementation of Occupational Safety and Health promotion programs being run as well as to fulfill one of the clauses in OHSAS 18001: 2007 on point 4.4. 4. About Documentation.

The following is the suitability of the implementation process of the Occupational Safety and Health promotion programs with related theory.

\section{Occupational Safety and Health Training}

Occupational Safety and Health training is a training that is organized and directed to equip, improve, and develop the capability, productivity, and welfare of the workforce [9]. Training is a process of assisting the workforce to gain effectiveness in their present or future work through the development of habits of thought, action, skills, knowledge and proper attitude. Based on the procedures, training K3 at PT. $\mathrm{X}$ consists of internal and external training. This Occupational Safety and health training program is implemented by Occupational Safety and Health unit in cooperation with HRD. As the training program implementer, Occupational Safety and Health unit PT. X has the authority to appoint trainers in accordance with the training that will be conducted.

The implementation of training activities in PT. X is done through several stages, namely before training stage, training implementation, and training evaluation, and report making. This is in line with the training phases issued by UNESCO, the pre-training stage, the phase after the first phase of the training (monitoring and evaluation), and the post-training phase 2 (Follow up and preparation of the training report). However, in the current implementation of the training module is still in the process so there is no raw material module to be given to the participants during the training.

\section{Occupational Safety and Health Counseling}

The implementation process of this program generally in accordance with the stages of the process that must be pursued in the implementation of health counseling proposed by
Effendy [8], which is to assess the needs; fix the problem; prioritize problems; drafting extension planning such as setting goals, targeting, preparing the material or content of counseling, selecting appropriate methods, determining the type of props to be used; implementation of counseling; assessment of outreach results; and follow-up of counseling. However, in the implementation of the new evaluation until the stage of measuring the outcome of the outreach results based on the observation data of existing events.

\section{Occupational Safety and Health Communication and Consultation}

Basically, the implementation of this program in accordance with the purpose of communication itself, where between transmitter information and recipient information to understand or understand the message delivered. In this case, the information submitted by the Occupational Safety and Health unit is related to the new worker's Occupational Safety and Health orientation, the guest or the apprentice / PKL student coming to PT. X in the form of safety induction. The implementation of consultation related to aspects of Occupational Safety and Health conducted in PT. X in accordance with the intended purpose, which is to provide help or in this case the advice to workers related to problems experienced by workers.

\section{Occupational Safety and Health Award}

Based on the results of interviews and document reviews, the implementation of Occupational Safety and Health awards activities that have been done in PT. X in accordance with the theory, which is what an organization should be able to give awards related to Occupational Safety and Health that can encourage employees want to do more in the effort to prevent accidents and occupational diseases in the company.

\section{REFERENCES}

[1] International Labor Organization. "Occupational Safety and Health Means for Productivity. Jakarta: International Labor Offce, 2013.

[2] Employee Social Security System (BPJS Ketenagakerjaan). "The number of accidents in Indonesia is still high," BPJS Ketenagakerjaan, Januari 2016

[3] Ministry of Public Works. Implementation of SMK3 in Construction Projects Reduce Work Accidents. Ministry of Public Works, 2015.

[4] Carl dan Diane, Health Promotion Programs: From Theory To Practice. US: Society for Public Health Education, 2010.

[5] C.E. Shannon, D. Warren Weaver, The Mathematical Theory of Communication, Urbana: University of Illinois, 1949.

[6] Effendy and Makhfudli, Community Health Nursing: Theory and Practice in Nursing, Jakarta: Salemba Medika, 2009.

[7] Ministry of Health Republic of Indonesia, Code of Conduct Guidance Manual Clean and Healthy Living, Public Health Counseling Center, Jakarta, 2001

[8] A. Kholid, Health Promotion: With Approach to Theory of Behavior, Media, and Its Application, Jakarta: Rajawali Press, 2015.

[9] S. Ramli, Occupational Safety and Health Management System OHSAS 18001, Jakarta: Dian Rakyat, 2010. 